\title{
PROTESA MAKSILOFASIAL DENGAN HOLLOW BULB UNTUK REHABILITASI PASCA HEMIMAXILLECTOMY KLAS IV ARAMANY
}

\author{
Farid Munandar*, Heriyanti Amalia**, \& Endang Wahyuningtyas** \\ "Program Studi Prostodonsia, Program Pendidikan Dokter Gigi Spesialis, \\ Fakultas Kedokteran Gigi, Universitas Gadjah Mada, Yogyakarta \\ *Bagian Prostodonsia, Fakultas Kedokteran Gigi Universitas Gadjah Mada, Yogyakarta
}

\begin{abstract}
ABSTRAK
Latar belakang. Tindakan operasi pembedahan pada daerah wajah akan mengakibatkan cacat wajah, gangguan fungsi bicara, penelanan, pengunyahan, estetik serta kejiwaan penderita dan dapat menimbulkan masalah pada rehabilitasinya.

Tujuan. Penulisan laporan ini untuk menginformasikan bahwa defect atau cacat pada daerah wajah dapat direhabilitasi dengan pembuatan protesa maksilofasial dengan hollow bulb untuk mengembalikan fungsi.

Kasus. Pasien laki-laki berusia 30 tahun datang ke RSGM atas rujukan dari R.S.Dr.Sardjito. Saat datang pasien merasa terganggu dengan adanya defect didalam mulutnya. Operasi hemimaxillectomy telah dilakukan oleh dokter THT R.S Hasan Sadikin setahun yang lalu.

Penanganan. Dilakukan pemeriksaan subyektif, obyektif, radiografi dan hasil diagnose terdapat defect klas IV Aramany. Rehabilitasi dapat dilakukan dengan pembuatan protesa maksilofasial dengan hollow bulb klas IV Aramany untuk mengembalikan fungsi dan menghindari akibat dari pasca operasi hemimaxillectomy lebih lanjut. Pemeriksaan retensi, stabilisasi, oklusi, estetik dan pengucapan dilakukan pada waktu insersi, begitu pula pada saat kontrol 1 minggu dan 1 bulan setelah pemakaian tidak ada keluhan.

Kesimpulan. Pemakaian protesa maksilofasial dengan hollow bulb ini dapat berguna sebagai alat rehabilitasi yang dapat mengembalikan fungsi bicara dan mengunyah, estetik dan membantu proses penyembuhan jaringan dan psikologi penderita. Maj
\end{abstract} Ked Gi;, Juni 2011; 18(1): 73-76

Kata kunci: protesa maksilofasial, hollow bulb, Klas IV Aramany, hemimaxillectomy.

\section{ABSTRACT}

Background. The surgery procedure on the face will cause facial defects, malfunctioning of talking, swallowing, mastication, esthetic and psychological and may cause problem in the rehabilitation.

Purpose. The aim of this paper is to inform that facial defect can be repair the malfunction through maxillofacial prothesa with hollow bulb.

Case. Male patient, 30 years old refered from R.S. Sardjito to RSGM prof. Soedomo. The patient disturbed with defect in the oral cavity. Hemimaxillectomy surgery done by ENT specialistic in R.S. Hasan Sadikin one year ago.

Treatment. Then get a subjective, objective and radiographic examination and result diagnose is defect Aramany class IV. Rehabititation can do maxillofacial prothesa Aramany class IV with hollow bulb to recover the function and avoiding further effect post hemimaxillecomy surgery. At the time of insertion, check out the retention, stabilization, occlusion, esthetic and pronounciation, as well as 1 week and 1 month after used. There is no complaint after prothesa insertion.

Conclusion. Maxillofacial prothesa with hollow bulb useful as an appliance rehabilitation that can restore speech and chewing function, esthetic and support tissue healing process and the psychology of patient. Maj Ked Gi, Juni 2011; 18(1): 73-76

Key words: maxillofacial prothesa, hollow bulb, Aramany class IV, hemimaxillectom

\section{PENDAHULUAN}

Pembesaran di daerah maksilofasial dilakukan terapi dengan pembedahan yaitu reseksi daerah maksilofasial untuk menghilangkan tumor atau lesi lokal yang menyebabkan terjadinya cacat berupa perforasi pada langit-langit yang disebut defect . Tindakan operasi pembedahan pada daerah wajah akan mengakibatkan cacat wajah, gangguan fungsi bicara, penelanan, pengunyahan, estetik serta kejiwaan penderita dan dapat menimbulkan masalah pada rehabilitasinya. Besarnya masalah yang akan terjadi tergantung pada luasnya tindakan reseksi yang akan dilakukan dan cara pengembalian bentuk wajah ke keadaan normal serta faktor psikologi penderita untuk menerima kenyataan yang dialaminya .$^{2}$ Penggantian jaringan gigi dan mulut yang diambil pada waktu operasi sangat dibutuhkan rehabilitasinya dengan pembuatan protesa maksilofasial ${ }^{1}$.

Hemimaxillectomy ialah tindakan operasi atau reseksi dari maksila dengan mengambil sebagian tulang maksila pada satu sisi. Tindakan maksilektomi ada tiga macam yaitu maksilektomi marginal, maksilektomi total dan maksilektomi radikal. Dalam menentukan pilihan tindakan maksilektomi tergantung pada kerusakan tulang. ${ }^{3}$ Klasifikasi defect yang ter- 
jadi pasca maxillectomy dibagi menjadi enam yaitu :

1. Klas I Aramany defect unilateral mengenai seluruh gigi posterior dan anterior

2. Klas II Aramany defect unilateral mengenai gigi posterior

3. Klas III defect hanya pada palatum

4. Klas IV defect bilateral mengenai seluruh gigi anterior dan seluruh gigi posterior pada satu sisi

5. Klas $\vee$ defect bilateral mengenai seluruh gigi posterior baik sisi kanan maupun kiri melewati garis tengah

6. Klas VI defect bilateral hanya mengenai seluruh gigi anterior.

Protesa maksilofasial adalah protesa yang menutup celah abnormal antara rongga mulut dan rongga hidung, digunakan untuk rehabilitasi fungsi oral dan estetik dengan melakukan penggantian bagian yang rusak atau hilang dengan memakai protesanya. ${ }^{4}$ Protesa maksilofasial pasca hemimaxillectomy dibuatkan protesa pasca bedah yang dibuat sebelum operasi dan dipasang pada saat operasi yang berguna sebagai pegangan tampon, mempercepat penyembuhan luka dan mengurangi kontaminasi bakteri sehingga infeksi dapat dicegah. Setelah 2 minggu pasca bedah dibuatkan protesa maksilofasial definitive yang bertujuan mengembalikan fungsi bicara dan mengunyah, membantu proses penyembuhan jaringan lunak,memperbaiki bentuk muka setelah kehilangan sebagian tulang fasial dan membantu psikologis penderita. ${ }^{5}$ Protesa maksilofasial dibuat segera setelah operasi, karena apabila terlambat akan terjadi kontraksi otot-otot wajah yang dapat menyebabkan retensi berkurang, sehingga penderita menjadi cacat dan kecewa. ${ }^{6}$ Protesa maksilofasial dapat dibuat dari bahan logam maupun akrilik, tapi lebih sering digunakan bahan akrilik yang relatif lebih murah. $^{7}$

Hollow bulb adalah rongga yang dibuat untuk menutup rongga mulut, rongga hidung dan defect. ${ }^{8}$ Protesa maksilo fasial dapat dibuat dengan dua cara yaitu one-piece hollow bulb dan two-piece hollow bulb. One-piece hollow bulb adalah pembuatan maksilo fasial hollow dengan membentuk shim didalam protesa maksilo fasial. Shim adalah rongga dengan dinding yang terbuat dari self curing acrylic resin. Two-piece hollow bulb adalah protesa maksilo fasial yang terdiri dari dua bagian, yaitu protesa maksilo fasial dengan hollow yang terbuka dan bagian tutup hollow yang terbuat dari heat curing acrylic resin dan direkatkan dengan self curing acrylic resin. Teknik ini sering digunakan untuk membuat protesa maksilo fasial dengan hollow karena cara pembuatannya lebih mudah daripada one-piece hollow bulb. ${ }^{8}$
Desain dari protesa maksilofasial pada umumnya sama dengan desain gigi tiruan konvensional yaitu diperlukan suatu base plate, konektor, adanya komponen yang mendukung untuk stabilisasi dan retensi.

Tujuan penulisan laporan ini untuk menginformasikan bahwa defect atau cacat pada daerah wajah dapat dibuatkan suatu protesa maksilofasial untuk mengembalikan fungsi bicara, penelanan, pengunyahan, estetik serta kejiwaan penderita.

\section{LAPORAN KASUS}

Pasien laki-laki berusia 30 tahun, status mahasiswa, datang ke klinik Prostodonsia FKG -UGM. Pada pemeriksaan subyektif pasien merasa terganggu dengan adanya defect didalam mulutnya. Pemeriksaan objektif, secara extra oral muka tampak asimetris terdapat cekungan pada pipi sebelah kanan. Intra oral terdapat defect dimulai dari tengah palatum meluas sampai ke anterior kanan kiri dan bukal dengan oral hygiene yang buruk. Gigi yang tersisa setelah dilakukan operasi 24,25,26,27 dengan diagnose defect klasifikasi Kelas IV Aramany. Perawatan yang akan dilakukan adalah pembuatan protesa maksilofasial definitive dengan hollow bulb.

Tahap pertama, dilakukan pencetakan rahang atas dan bawah untuk pembuatan study model dengan menggunakan perforated stock tray dengan bahan cetak hydrocolloid irreversible (alginate). Cara pencetakannya sebelum bahan cetak dimasukkan kedalam mulut, pada alginate diberi kain kassa hanya pada sisi defect untuk menahan agar bahan cetak tidak masuk ke hidung, kemudian hasil cetakan diisi stone gips.

Tahap kedua, pembuatan maksilo fasial sementara dengan bahan shellac dilakukan supaya pasien tidak terganggu pada saat pengunyahan. Untuk mendapatkan retensi dengan membuat beberapa lubang pada shellac di regio interdental gigi 24,25 , 26, 27 yang masih kuat dan sehat sebagai tempat untuk wire/kawat $(0,3 \mathrm{~mm})$ yang akan memegang obturator

Tahap ketiga pembuatan maksilo fasial definitive dilakukan pencetakan rahang atas dan rahang bawah dengan bahan cetak alginate untuk membuat model kerja dengan cara yang sama dengan pencetakan sebelumnya. Hasil cetakan diisi dengan stone gips. Obturator sementara dipasang kembali sampai pembuatan obturator definitive selesai.

Desain maksilo fasial definitive dengan memakai $\mathrm{C}$ klamer untuk gigi pegangan $24,25,26$ dan 27. Membuat model malam pada rahang atas untuk plat dasar 
gigi tiruan.Kemudian proses laboraturium.

\section{Desain Obturator :}

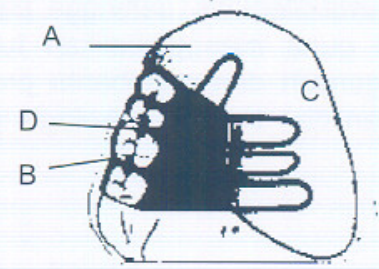

Keterangan
A. basis protesa
B. C-klamer
C. gigi anasir
D. Hollow bulb

Pada tahap keempat maksilo fasial sementara dilepas. Dilakukan try in base plate, yang perlu diperhatikan adalah retensi dan stabilisasi, serta plat tidak menimbulkan tekanan, iritasi atau sakit pada jaringan mulut. Membuat galangan gigit pada sisi defect setinggi gigi yang masih ada pada sisi yang sehat. Pencatatan relasi maksila dan mandibula (MMR) dengan metode willis. Vertikal dimensi didapat dengan cara $\mathrm{HD}=\mathrm{PM}-2$. Membuat catatan gigitan pada sisi rahang yang sehat dengan menggigit dua lembar malam lunak untuk mendapatkan catatan oklusi. Mencocokkan warna gigi ( A 3, VITA ). Model rahang atas basis protesa dengan hollow bulb dan rahang bawah dioklusikan menggunakan catatan gigitan, kemudian dipasang pada artikulator. Pemasangan gigi tiruan ,23,22,21,11,12,13,14,15,16,17 dan dilanjutkan dengan model malam.

Pada tahap kelima dilakukan try-in protesa maksilo fasial dengan hollow bulb, yang perlu diperhatikan adalah retensi, stabilisasi, oklusi, estetik dan fonetik. Pasien diminta mengucapkan huruf $s, b, p$, $v$ dan lain-lain untuk memeriksa kejelasan suara kemudian proses laboratorium. Obturator sementara dipasang kembali sampai kunjungan berikutnya.

Pada tahap keenam dilakukan insersi maksilo fasial dengan hollow bulb yang perlu diperhatikan adalah retensi, ketepatan fitting surface basis protesa pada mukosa dan pada daerah defect, $\mathrm{C}$ klamer sebagai direct retainer benar-benar memeluk gigi pegangan dan tidak menekan, tepi plat menempel pada cingulum gigi asli berfungsi sebagai indirect retainer. Stabilisasi, obturator tetap stabil pada saat dilakukan gerakan fungsi rahang. Oklusi, gangguan oklusi dapat diketahui dengan menggunakan kertas artikulasi. Dilakukan pengurangan pada daerah traumatik oklusi. Estetik, adanya protesa sangat membantu penampilan gigi dan wajah pasien menjadi lebih baik. Instruksi pada pasien cara pemakaian dan melepas protesa, pasien diminta untuk bisa beradaptasi dengan protesanya, pemeliharaan/membersihkan protesanya setiap habis makan,melepas protesa pada saat tidur/malam hari dan direndam dalam air bersih,menjaga kebersihan rongga mulut dan protesanya, kontrol satu minggu dan 1 bulan kemudian.

Pada waktu kontrol satu minggu setelah pe- makaian, dilakukan pemeriksaan subyektif tidak ada rasa sakit, tertekan maupun longgar pada waktu protesa dipakai untuk berfungsi. Pada pemeriksaan obyektif, oklusi baik,pengucapan huruf dan berbicara jelas, tidak terdapat iritasi pada jaringan mukosa mulut. Kontol satu bulan kemudian.

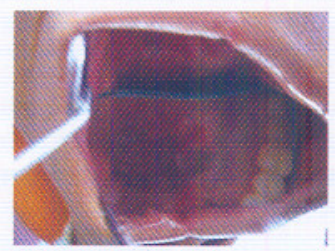

Gambar 5. Foto defect klas IV Aramany

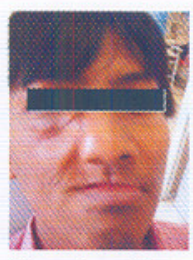

Gambar 6. Foto tidak memakai obturator

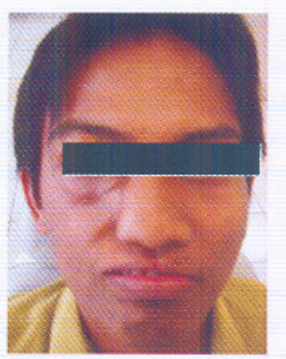

Gambar 7. Foto profil setelah memakai obturator

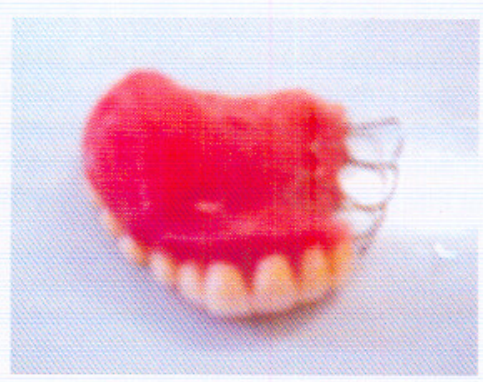

Gambar 8. Obturator dari bukal

\section{PEMBAHASAN}

Perubahan anatomi pada pasien pasca hemimaxillektomy menyebabkan berbagai macam respon fisik dan emosional pasien terutama yang sangat dirasakan pasien adalah perubahan estetik, hilangnya fungsi, dan rasa tidak nyaman. Rehabilitasi dengan protesa maksilo fasial dapat membantu mengurangi penderitaan pasien.

Pasien telah dilakukan operasi hemimaxillektomy setahun yang lalu sehingga dibuatkan protesa 
maksilofasial sementara untuk mencegah kontaminasi dengan bakteri, sehingga infeksi bisa dicegah, membantu pasien untuk bisa berbicara lebih efektif selama pembutan obturator definitive, mempercepat penyembuhan dan mengurangi beban psikologis. Pembuatan maksilo fasial definitif dengan hollow bulb yang diperluas ke dalam defect, selain untuk menutup defect secara maksimal, protesa menjadi lebih ringan sehingga menambah retensi dan stabilisasi. Hollow bulb yang digunakan dalam kasus ini adalah hollow bulb one-piece. Penggunaan maksilo fasial dengan hollow bulb disini memiliki beberapa keuntungan yaitu: (1) mudah dalam pembuatannya, (2) memiliki berat yang lebih ringan (3) memberikan retensi yang baik, dan (4) pengucapan bunyi lebih jelas.

Pada waktu insersi, diperiksa retensi, stabilisasi, oklusi, estetik, pengucapan dan pembicaraan sudah dapat dimengerti oleh lawan bicaranya atau operator karena sudah tidak ada celah antara protesa dan jaringan dibawahnya. Wajah pasien lebih simetris, defect sudah berkurang. Pembuatan tepi protesa yang tepat akan menambah retensi, stabilisasi dan oklusi menjadi lebih baik. Hal ini menunjukkan bahwa keberhasilan dalam membuat protesa maksilofasial ditentukan oleh ketepatan pembuatan tepi protesa atau peripheral seal. ${ }^{9}$ Estetik menjadi baik karena protesa maksilofasial dapat mendukung wajah dengan baik dan menutup daerah defect. Suara dan pengucapan huruf menjadi lebih jelas karena tidak ada celah antara protesa dan jaringan dibawahnya karena hilangnya struktur maksilofasial tidak hanya mengubah ruang artikulasi bicara, tetapi berpengaruh juga pada kejelasan suara dan pengucapan kata. ${ }^{8}$

Pada waktu kontrol 1 minggu dan 1 bulan setelah pemakaian hasilnya tidak ada keluhan, tidak ada rasa tertekan, sakit maupun longgar pada waktu protesa dipakai untuk berbicara maupun mengunyah, oklusi baik, pengucapan huruf dan bicara terdengar jelas, tidak terdapat iritasi pada jaringan, pasien lebih percaya diri.

\section{KESIMPULAN}

Protesa maksilofasial dengan hollow bulb merupakan alat rehabilitasi yang harus segera dibuat setelah operasi hemimaxillectomy sehingga pasien dapat hidup normal guna mengembalikan fungsi bicara, estetik, mengunyah dan membantu proses penyembuhan jaringan dan trauma psikologis penderita.

\section{DAFTAR PUSTAKA}

1. Light J: Fuctional Assessment testing for Maxillofacial Prosthetics, J. Prosthet Dent , 1997; 77(4):388- 393

2. Argerakis GP: Psychosocial Consideration of the Post Treatment of Head and Neck Cancer Patients, Dental Clinics of North America, $1990 ; 34: 285-305$.

3. Rankow RM: An Atlas of Surgery of the Face, Mouth and Neck, W.B. Saunders Company, Philadelphia, $1968 ; 100-129$.

4. Schaaf NG \& Wu Y: Comparison of weight reduction in different designs of solid and hollow obturator, J. Prosthet Dent, $1989 ; 62: 214-217$

5. Wolfaardt JF: Modifying a Surgical Obturator Prosthesis, J. Prosthet Dent, 1989 ; 62 : 619-621.

6. Laney WR and Gilbilisco JA: Diagnostic and Treatment in Prosthodonthic, $1983 ; 415-445$

7. Da Breo EL, Chalian VA, Lingeman R, \& Reisbick HM: Prosthetic and Surgical Management of Osteogenic Sarcoma of the Maxilla, J. Prosthet Dent, $1990 ; 63$ : 316-319

8. Hammond RJ \& Berger OE: Increased Vertical Dimension and Speech Articulation Erros, J.Prosthet Dent, $1984 ; 52(3): 401-405$.

9. Da Breo EL, Chalian VA, Lingeman R, \& Reisbick HM: Principles Concepts and Practice in Prosthodontics, $\mathrm{J}$. Prosthet Dent, $1994 ; 71$ : 73-88. 